\title{
MET NP_000236.2:p.V1070M
}

National Cancer Institute

\section{Source}

National Cancer Institute. MET NP 000236.2:p.V1070M. NCI Thesaurus. Code C162294.

A change in the amino acid residue at position 1070 in the hepatocyte growth factor receptor protein where valine has been replaced by methionine. 